\title{
Review
}

\section{The Regulatory Functions of $\sigma^{54}$ Factor in Phytopathogenic Bacteria}

\author{
Chao Yu ${ }^{1}$, Fenghuan Yang ${ }^{1}$, Dingrong Xue ${ }^{2} \mathbb{D}$, Xiuna Wang ${ }^{3}$ and Huamin Chen ${ }^{1, * \mathbb{C}}$ \\ 1 State Key Laboratory for Biology of Plant Diseases and Insect Pests, Institute of Plant Protection, Chinese \\ Academy of Agricultural Sciences, Beijing 100193, China; yuchao@caas.cn (C.Y.); yangfenghuan@caas.cn (F.Y.) \\ 2 National Engineering Laboratory of Grain Storage and Logistics, Academy of National Food and Strategic \\ Reserves Administration, No. 11 Baiwanzhuang Street, Xicheng District, Beijing 100037, China; xdr@ags.ac.cn \\ 3 Key Laboratory of Pathogenic Fungi and Mycotoxins of Fujian Province, Key Laboratory of Biopesticide and \\ Chemical Biology of Education Ministry, School of Life Sciences, Fujian Agriculture and Forestry University, \\ Fuzhou 350002, China; xiuna0304@163.com \\ * Correspondence: chenhuamin@caas.cn
}

Citation: Yu, C.; Yang, F.; Xue, D.; Wang, X.; Chen, H. The Regulatory Functions of $\sigma^{54}$ Factor in

Phytopathogenic Bacteria. Int. J. Mol. Sci. 2021, 22, 12692. https://doi.org/ $10.3390 /$ ijms222312692

Academic Editor: Jan Kormanec

Received: 14 October 2021

Accepted: 22 November 2021

Published: 24 November 2021

Publisher's Note: MDPI stays neutral with regard to jurisdictional claims in published maps and institutional affiliations.

Copyright: (c) 2021 by the authors. Licensee MDPI, Basel, Switzerland. This article is an open access article distributed under the terms and conditions of the Creative Commons Attribution (CC BY) license (https:// creativecommons.org/licenses/by/ $4.0 /)$.

\begin{abstract}
RpoN), a type of transcriptional regulatory factor, is widely found in pathogenic bacteria. It binds to core RNA polymerase (RNAP) and regulates the transcription of many functional genes in an enhancer-binding protein (EBP)-dependent manner. $\sigma^{54}$ has two conserved functional domains: the activator-interacting domain located at the N-terminal and the DNA-binding domain located at the C-terminal. RpoN directly binds to the highly conserved sequence, $\mathrm{GGN}_{10} \mathrm{GC}$, at the $-24 /-12$ position relative to the transcription start site of target genes. In general, bacteria contain one or two RpoNs but multiple EBPs. A single RpoN can bind to different EBPs in order to regulate various biological functions. Thus, the overlapping and unique regulatory pathways of two RpoNs and multiple EBP-dependent regulatory pathways form a complex regulatory network in bacteria. However, the regulatory role of RpoN and EBPs is still poorly understood in phytopathogenic bacteria, which cause economically important crop diseases and pose a serious threat to world food security. In this review, we summarize the current knowledge on the regulatory function of RpoN, including swimming motility, flagella synthesis, bacterial growth, type IV pilus (T4Ps), twitching motility, type III secretion system (T3SS), and virulence-associated phenotypes in phytopathogenic bacteria. These findings and knowledge prove the key regulatory role of RpoN in bacterial growth and pathogenesis, as well as lay the groundwork for further elucidation of the complex regulatory network of RpoN in bacteria.
\end{abstract}

Keywords: $\sigma^{54}$ factor; enhancer-binding proteins; motility; T3SS; virulence

\section{Introduction}

Transcription factors play a crucial role in microbial growth and response to environmental changes by regulating the expression of target genes. In bacteria, sigma $(\sigma)$ factors are the most widely occurring transcription factors. They reversibly bind RNA polymerase (RNAP) to regulate the transcription of a myriad of functional genes. To initiate the RNA synthesis, $\sigma$ factors guide RNAP holoenzyme to specific promoters, melt double-stranded promoter DNA strands, and stabilize them as a single-stranded open complex [1-3]. According to their structure and evolution, $\sigma$ factors are categorized into (a) the $\sigma^{70}$ family and (b) the $\sigma^{54}$ family (also called RpoN) [4]. In general, $\sigma^{70}$ factors regulate the transcription of target genes by recognizing the $-35 /-10$ promoter site (upstream from the transcription start site), while $\sigma^{54}$ factors regulate the transcription of target genes by recognizing the highly conserved sequence $\mathrm{GGN}_{10} \mathrm{GC}$ at the $-24 /-12$ promoter site $[5,6]$.

$\sigma^{54}$ factors act as a multifunctional regulator of many important biological processes. In Pseudomonas aeruginosa, $\sigma^{54}$ regulates global gene expression (680 genes) and a wide range of biological processes, such as flagella synthesis, motility, metabolism, antibiotic resistance, and virulence [7-10]. It affects the expression of nitrogen-regulated genes (ntrBC, $g \ln A, g \ln K-a m t B, \operatorname{nir} B D$, nas $A, n a s S T$, and nosRZDFYL) and flagellum-related genes 
(fleSR, fliEFGHIJ, flhA, flhF, fleN, flgA, fliLMNOPQR, and flhB) at the transcription level. Furthermore, $\sigma^{54}$ also regulates the susceptibility to tobramycin, quinolones, and carbapenems [11-14]. In P. putida, it also affects the utilization of nitrate, urea, and uncharged amino acids as nitrogen sources, as well as of lysine, $\mathrm{C}_{4}$-dicarboxylates, and alpha-ketoglutarate as carbon sources $[15,16]$. In addition, $\sigma^{54}$ factor controls bacterial growth [17-19], nitrogen and carbohydrate assimilation [20,21], swimming and twitching motility [22], biofilm formation [23,24], exopolysaccharide (EPS) production [23], quorum sensing [25,26], type VI secretion systems (T6SS) [27,28], virulence [29,30], environmental adaptation [31,32], and antibiotic resistance $[33,34]$ in other bacteria.

Unlike $\sigma^{70}$ factors, the regulatory function of $\sigma^{54}$ is dependent on transcriptional activators, i.e., enhancer-binding proteins (EBPs) [35]. EBPs generally contain three domains: (a) an N-terminal signal-sensing domain, whose primary function is to perceive signals and regulate the activity of transcription activators; (b) a central $\mathrm{AAA}^{+}$domain, whose primary function is to interact with the $\sigma^{54}$ factor and hydrolyze ATP to release energy; (c) a C-terminal DNA-binding domain, whose primary function is to bind to gene promoters [4,36-38]. The central $\mathrm{AAA}^{+}$domain is the most conserved domain, and it is present in all EBPs. Thus, candidate EBPs can be identified using central $\mathrm{AAA}^{+}$conserved domains, and their regulatory roles in bacteria can be further analyzed.

In general, bacteria only contain one or two $\sigma^{54}$ factors, but have multiple EBPs. For instance, P. aeruginosa contains one $\sigma^{54}$ factor and a group of EBPs. Different stress-related signals regulate these EBPs through their N-terminal regulatory domains [39]. Two EBPs, DdaR and MifR, interact with the $\sigma^{54}$ factor to induce the transcription of dimethylarginine dimethylaminohydrolase and PA5530 genes by sensing aromatic amino acids and extracellular $C_{5}$-dicarboxylates, respectively $[40,41]$. In addition, the $\sigma^{54}$ factor regulates the glyoxylate pathway, ethanolamine catabolism, $(R)$-3-hydroxybutyrate, the glycine cleavage system, and pyocyanin biosynthesis via EatR, $\mathrm{HbcR}$, and GcsR, respectively [42-45]. Other EBPs, including PhhR, FleQ, AlgB, FhpR, CbrB, NtrC, DctD, FleR, RtcR, PilR, SfnR1, AauR, and $\mathrm{Sfa} 3$, and their regulatory roles in metabolism, motility, and virulence have also been studied in P. aeruginosa $[13,15,46-51]$. These results indicated that the $\sigma^{54}$ factor forms a complex regulatory network with these EBPs, and whether these EBPs have overlapping regulatory roles needs further study. Moreover, numerous EBPs and their roles have been identified in other human and animal pathogenic bacteria [52,53]. However, the regulatory roles of the $\sigma^{54}$ factor and EBPs in phytopathogenic bacteria remain largely unexplored.

Phytopathogenic bacteria, such as fungi and viruses, cause economically important plant diseases and pose a serious threat to world food security. P. syringae, Ralstonia solanacearum, Xanthomonas species, Erwinia amylovora, and Dickeya dadantii are the most important phytopathogenic bacteria [54]. P. syringae causes important crop diseases, and it is a well-known model organism for plant-pathogen interaction-related study. $R$. solanacearum is probably the most destructive pathogen worldwide, and it has a very broad host range that can infect 200 plant species belonging to over 50 plant families. X. oryzae pv. oryzae $(\mathrm{Xoo})$ and oryzicola $(\mathrm{Xoc})$ are the most important bacterial pathogens of rice, resulting in a $20-50 \%$ loss of crop yield. X. campestris pv. campestris $(X c c)$ is the causative agent of black rot of crucifers and affects cultivated brassicas worldwide. E. amylovora causes fire blight disease of apple, pear, quince, blackberry, and raspberry, and it threatens the safe production of major fruits. $D$. dadantii causes disease mainly in tropical and subtropical environments and has a wide host range, including Saintpaulia and potato. In this review, we summarized the recent research on the $\sigma^{54}$ factor and its regulatory functions in these phytopathogenic bacteria to enhance the current understanding of the regulatory mechanism of phytopathogenic bacteria's motility, growth, and virulence.

\section{The $\sigma^{54}$ Factor-Mediated Transcriptional Regulation}

The $\sigma^{54}$ factor (RpoN) has two conserved functional domains: an N-terminal activatorinteracting domain (AID) and a C-terminal DNA-binding domain (DBD). AID performs two distinct functions: (i) inhibition of polymerase isomerization and initiation in the 
absence of activation; (ii) interaction with EBPs and stimulation of initiation in response to activation after binding to EBPs $[55,56]$. Unlike $\sigma^{70}, \mathrm{RpoN}$ is dependent on EBPs to regulate gene transcription. Firstly, the transcription process involves the binding of the RpoN-RNAP holoenzyme to a target gene promoter at -24 / -12 base pairs relative to the start codon, followed by a closed complex formation. The DNA in this complex remains in an inactive, closed state. Secondly, EBP binds to the target gene promoter sequence at nearly -150 base pairs relative to the RpoN binding sites. Thirdly, the RpoN interacts directly with the EBP AAA ${ }^{+}$domain and hydrolyzes ATP to release energy. Lastly, the EBPs assemble into a catalytically competent oligomer upon getting stimulated by a cellular signal and remodel the RpoN-RNAP promoter complex using ATP. ATP hydrolysis opens the RpoN-RNAP-DNA complex and initiates RNA synthesis [6,37].

\section{The RpoN and EBPs in Major Phytopathogenic Bacteria}

The majority of phytopathogenic bacteria contain either one or two RpoN factors (Table 1). Two copies of rpoN, namely, rpoN1 and rpoN2, were identified in the Xanthomonas genome. $r p o N 1$ and $r p o N 2$ are primarily located in a phosphotransferase system and a large flagellar gene cluster, respectively [57-60]. The nucleotide sequences of rpoN1 and rpoN2 are not identical, and their protein sequences share 39\% identity [61]. It is well known that RpoN2 interacts with FleQ, an important EBP, and regulates flagellar-associated gene transcription, which controls flagellum synthesis and swimming motility $[57,61]$. PilRX, an EBP type, is located in the T4P gene cluster and forms a two-component system with PilSX [62]. In Xoo, RpoN2 positively regulates twitching motility and virulence in a PilRXdependent manner. The other four candidate EBPs that contain the $\mathrm{AAA}^{+}$domain were identified in Xoo (Figure 1). PrpR is a propionate catabolism operon regulatory protein, and it can interact with both RpoN1 and RpoN2. Deletion of prpR decreased the expression of prpBC and reduced Xoo growth and virulence (data unpublished). PXO_03020, PXO_03564, and PXO_03965 are NtrC family proteins, and their functions have not been studied in Xoo so far. The RpoN2 regulatory effects on virulence and growth have also been reported in other Xanthomonas species [58], but the type of EBP involved in these regulatory processes remains elusive. In the R. solanacearum genome, rpoN1 and rpoN2 are present in the chromosome and megaplasmid, respectively. Interestingly, RpoN1 but not RpoN2 is required for T4P gene expression, twitching motility, and virulence in bacteria [63,64]. A single RpoN has been found in P. syringae, which depends on two T3SS regulators, HrpS and HrpR, to regulate HrpL-dependent T3SS gene expression and control virulence $[65,66]$. Unlike in P. syringae, HrpS activates the hrpL transcription by binding to RpoN, but HrpR has not been found in E. amylovora and D. dadantii [67-69].

In the RpoN phylogenetic tree, the major phytopathogenic bacteria were divided into two groups. Group I included Xanthomonas spp., and group II included R. solanacearum, $P$. syringae, E. amylovora, and D. dadantii (Figure 2). Group I was further subdivided into two subgroups according to RpoN1 and RpoN2. Similarly, group II was also subdivided into two subgroups: (a) R. solanacearum with two copies of RpoN, and (b) P. syringae, E. amylovora, and $D$. dadantii with a single RpoN. The different classifications in the phylogenetic tree indicated that single and multiple RpoN factors might have different regulatory models in phytopathogenic bacteria. 
Table 1. The RpoNs and EBPs in major phytopathogenic bacteria.

\begin{tabular}{|c|c|c|c|c|}
\hline Bacteria & $\sigma^{54}$ Factors & EBPs & Target Genes & Functions \\
\hline \multirow{2}{*}{ Xanthomonas oryzae } & RpoN1 & $\operatorname{PrpR}$ & $\operatorname{prpBC}$ & Growth, virulence [59] \\
\hline & RpoN2 & FleQ, PilRX, PrpR & $\begin{array}{l}\text { fliA, fliC, fliTX, pilA, } \\
\text { pilC, } \operatorname{prpBC}\end{array}$ & $\begin{array}{c}\text { Growth, swimming, twitching, } \\
\text { virulence }[61,62,70]\end{array}$ \\
\hline \multirow{2}{*}{$\begin{array}{l}\text { Xanthomonas } \\
\text { campestris }\end{array}$} & RpoN1 & - & - & $\begin{array}{l}\text { DSF, branched-chain fatty-acid } \\
\text { production [58] }\end{array}$ \\
\hline & RpoN2 & FleQ & fliA, fliC & $\begin{array}{l}\text { Swimming, flagellum synthesis [57]; } \\
\text { biofilm, EPS, virulence [58] }\end{array}$ \\
\hline \multirow{2}{*}{ Xanthomonas citri } & RpoN1 & - & - & Swimming, virulence, growth [60] \\
\hline & RpoN2 & FleQ & fliC;flgG & Swimming, virulence, growth $[60,71]$ \\
\hline \multirow{2}{*}{$\begin{array}{c}\text { Ralstonia } \\
\text { solanacearum }\end{array}$} & RpoN1 & PehR & pilA & Twitching, growth, virulence $[63,64]$ \\
\hline & RpoN2 & - & - & - \\
\hline $\begin{array}{l}\text { Pseudomonas } \\
\text { syringae }\end{array}$ & RpoN & HrpR, HrpS, CbrB & $h r p L, \operatorname{crc} X, \operatorname{crc} Z$ & $\begin{array}{c}\text { T3SS [65,72]; virulence [66]; coronatine } \\
\text { biosynthesis [73]; carbon source } \\
\text { utilization, growth [74] }\end{array}$ \\
\hline Erwinia amylovora & RpoN & HrpS & hrpL, ihf A, rsmB & $\begin{array}{l}\text { T3SS, motility, growth, } \\
\text { virulence }[67,68,75,76]\end{array}$ \\
\hline Dickeya dadantii & RpoN & HrpS & hrpL & T3SS, virulence [69] \\
\hline
\end{tabular}

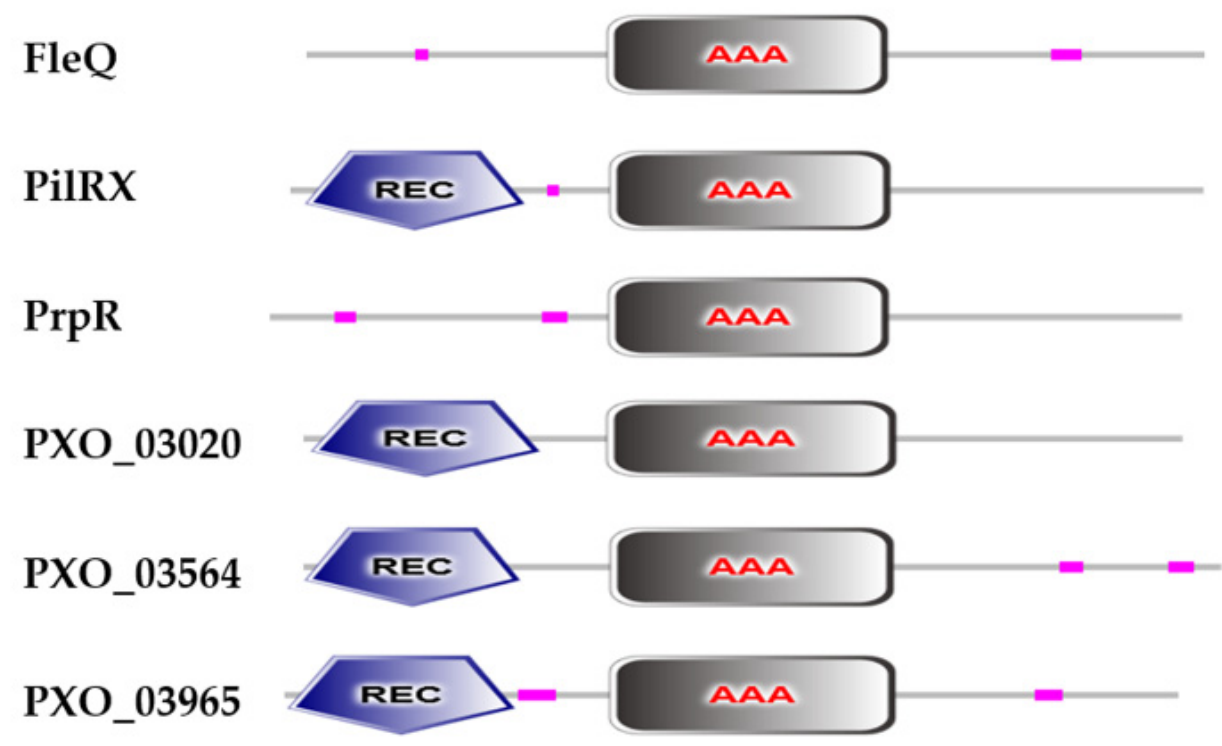

Figure 1. Six proteins containing an $\mathrm{AAA}^{+}$domain in Xoo. FleQ, PilRX and PrpR are three identified EBPs of RpoN. FleQ and PilRX interact with RpoN2 to regulate the synthesis of flagella and pili, thereby regulating swimming and twitching motility, respectively. PrpR combines with RpoN1 and RpoN2 to control Xoo growth. PXO_03020, PXO_03564, and PXO_03965 are NtrC family proteins, and their regulatory functions have not been studied in Xoo. REC, response regulator receiver domain; AAA, ATPase $\sigma^{54}$-interaction domain. The sequences of these proteins were downloaded from the NCBI website (https: / / www.ncbi.nlm.nih.gov / (accessed on 5 May 2021)), and conserved domains were analyzed by SMART (http:/ / smart.embl.de/smart/set_mode.cgi?NORMAL=1 (accessed on 5 May 2021)). 

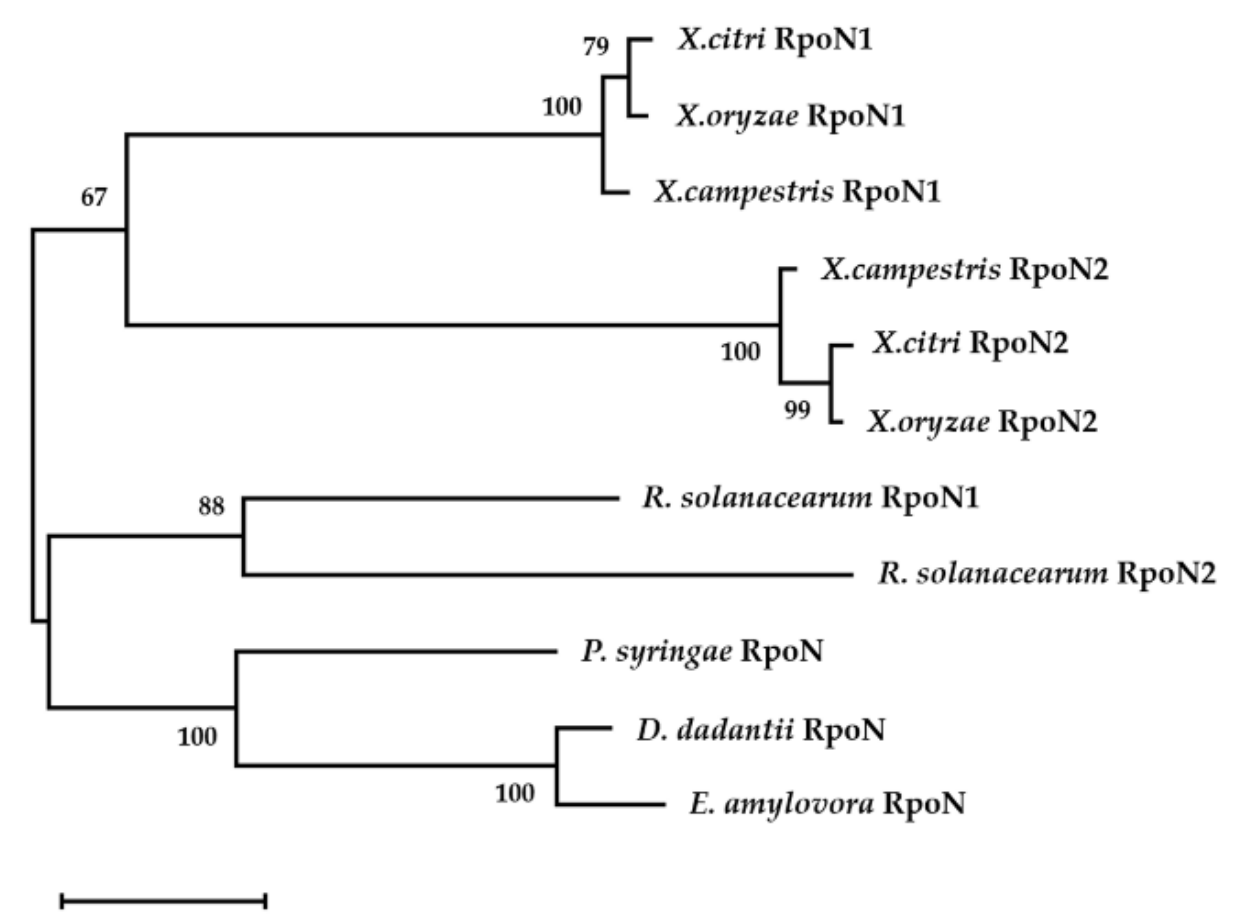

0.2

Figure 2. Phylogenetic analysis of RpoN. Eleven full-length RpoN protein sequences of X. oryzae, $X$. citri, X. campestris, $R$. solanacearum, P. syringae, D. dadantii, and E. amylovora were downloaded from the National Center for Biotechnology Information. A maximum likelihood (ML) tree was generated using MEGA-X with 1000 bootstrap values. Values on each branch represent the corresponding bootstrap probability. The scale bar indicates the number of amino-acid substitutions per site.

\section{RpoN Regulates Bacterial Flagella Synthesis and Motility}

Flagella are sophisticated organelles found in many bacteria where they perform functions related to motility, signal detection, biofilm formation, colonization, and attachment to host tissues. Flagellar assembly is a highly organized process that requires the temporal expression of dozens of genes, which are regulated hierarchically. In Xoo, a flagellar gene cluster containing over 60 contiguous genes, was identified. These genes encode functionally diverse proteins, such as structural component proteins, protein export apparatus, regulatory factors, and proteins involved in glycosylation and chemotaxis [61]. One of the $\sigma^{54}$ factor genes, rpoN2, is located in the central region of this gene cluster. In addition, $r p o N 2$ was transcribed in an operon with fleQ, which is located downstream of rpoN2 and encodes an EBP [61]. Further study revealed that the flagellar gene cluster is regulated under a three-tiered hierarchy by RpoN2/FleQ and $\sigma^{28}$ factor FliA (Figure 3). RpoN/FleQ, as the master regulators, control the expression of $\sigma^{28}$ factor FliA and flagellar structure component protein. Furthermore, FliA controls the expression of flagellin protein FliC, flagellar cap protein FliD, flagellar chaperone proteins FliS and FliTX, and anti- $\sigma^{28}$ factor FlgM [61]. Moreover, RpoN2/FleQ regulates the transcription of flagellin glycosylationrelated genes (gigx1-gigx10), chemotaxis-associated genes (cheYZA), and c-di-GMP-related genes (PXO 06199, PXO 06201, and PXO 06202) [59,77]. Deletions in rpoN2, fleQ, fliC, and fliA resulted in the loss of flagella and swimming motility in Xoo. Interestingly, the fleQ mutant did not show much difference in its ability to infect rice leaves compared to the wild type. In contrast, the rpoN2 mutant caused much less severe disease symptoms and shorter lesions [61]. This result indicated that RpoN2 might regulate Xoo virulence in a manner independent of flagellar motility. 


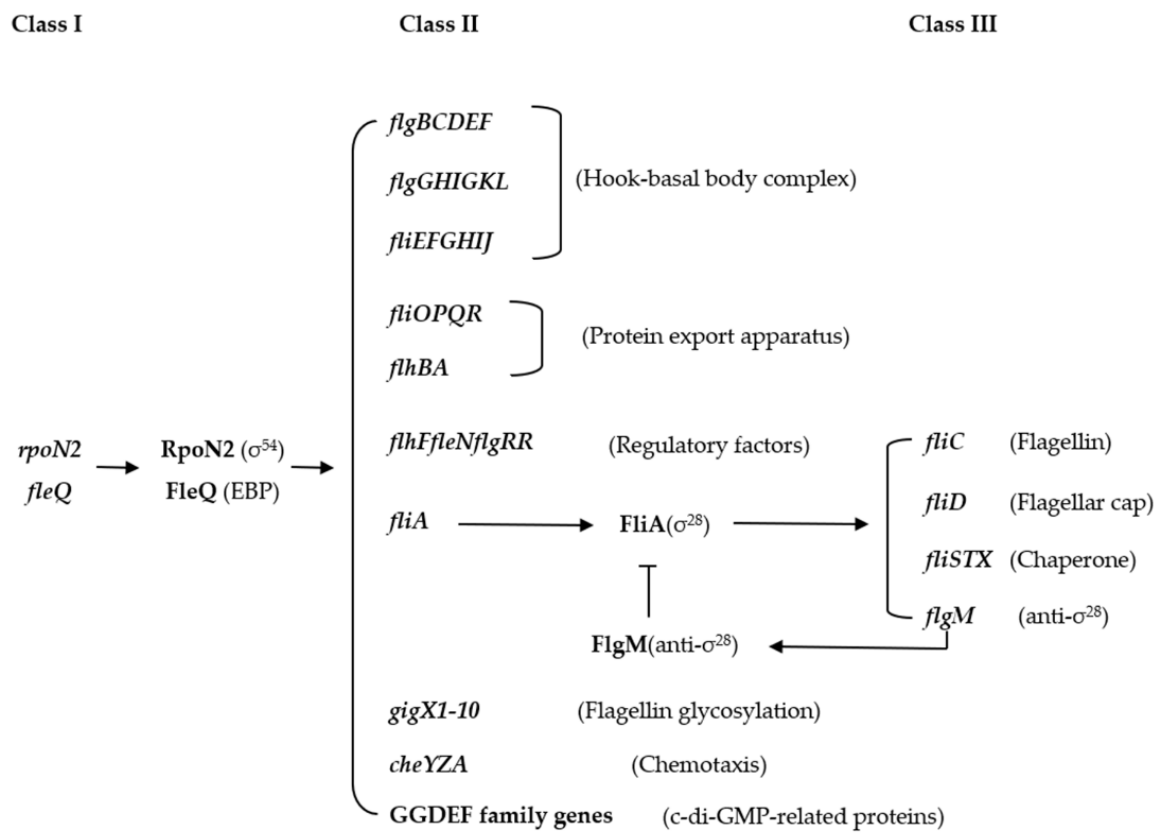

Figure 3. The three-tiered hierarchy of flagella synthesis in Xoo. The RpoN2 and FleQ, encoded by the class I genes rpoN2 and fleQ, are the master regulators and control the transcription of class II genes. The class II gene products include most of flagellum structural components, regulatory factors (FlhF, FleN and FlgRR), flagellin glycosylation-related proteins (GigX1-10), chemotaxis-related proteins (CheYZA), c-di-GMP synthesis and degradation related proteins, and alternative sigma factor FliA. FliA regulates the transcription of class III genes, which encode the flagellin FliC, the flagellar cap FliD, the flagellar chaperone proteins FliS and FliTX, and the anti- $\sigma^{28}$ factor FlgM. Interestingly, FlgM negatively regulates FliA activity and protects it from degradation.

Another $\sigma^{54}$ factor, RpoN1, was also identified in Xoo. Transcriptome analysis showed that RpoN1 and RpoN2 regulate more than 30 genes in flagellar regulon [59]. Interestingly, the rpoN2 expression level was decreased in the rpoN1 mutant; moreover, abnormal flagellum and decreased swimming motility were also reported in the rpoN1 mutant [59]. As per a previous study, RpoN1 indirectly regulates the RpoN2 transcription in Xoo [59]. These results indicate that RpoN1 and RpoN2 have overlapping regulatory roles in bacterial flagellum synthesis and swimming motility in Xoo.

In X. campestris and X. citri, RpoN1 and RpoN2 are also involved in flagellum synthesis and motility. RpoN2 positively regulates the transcription levels of flagellar synthesisrelated genes (filDCES, flhAB) and chemotaxis-related genes (cheABDRWY, mot $A B$ ). In $X$. campestris, rpoN2 mutant lacked the typical single polar flagellum and swimming motility [58]. However, rpoN1 mutants showed flagellar morphology and swimming motility identical to the wild-type strain, indicating that RpoN2, but not RpoN1, is required for flagellum synthesis and motility in X. campestris [58]. Interestingly, the transcription levels of eight flagellar biosynthesis genes $(f l h F, f l h B, f l i Q, f l i L, f l i E, f l i D, f l g G$, and $f l g B)$ and bacterial swimming motility decreased in $\triangle r p o N 2$, but increased in $\triangle r p o N 1$, suggesting that RpoN2 positively, but RpoN1 negatively regulates the flagellum synthesis and motility in X. citri [60].

\section{RpoN Is Required for Nutritional Metabolism and Growth}

In P. syringae, RpoN positively regulates the transcription of two ncRNAs, $\operatorname{crcZ}$ and $\operatorname{crc} X$, thereby regulating the utilization of multiple carbon and nitrogen sources and influencing bacterial growth $[74,78]$. This transcriptional regulation is activated by $\mathrm{CbrB}$, which is an EBP of RpoN and belongs to the NtrC family of response regulators [79-81]. CrbB binds to CrbA and forms a two-component system [79]: a conserved signal transduction system that regulates the cellular carbon and nitrogen balance and plays a central role in 
carbon catabolite repression in Pseudomonas species [82]. CbrA contains a domain similar to the solute/sodium symporter family proteins, and it is typically found in bacterial sensor kinases. CbrAB directly activates the transcription of sRNAs ( $c r c Z$ and $c r c Y)$ from RpoN-dependent promoters, which antagonize the repressing activity of $\mathrm{Hfq}-\mathrm{Crc}$, the key regulator of the carbon catabolite repression (CCR) process, positively regulating carbon metabolism $[83,84]$. Furthermore, $\mathrm{CbrAB}$ controls the expression of alginate biosynthetic genes and $\operatorname{rsm} A$. It is also required to accumulate the sigma factor RpoS and core metabolites of aromatic and sugar metabolism $[85,86]$. Importantly, $\mathrm{CbrAB}$ and the master nitrogen regulator $\mathrm{NtrBC}$ directly control $\mathrm{C} / \mathrm{N}$ homeostasis by regulating the transcription of histidine utilization genes (hut) [87]. When histidine is the sole source of $\mathrm{N}$, the CbrAB-mediated promoter activity is weak, and NtrBC plays the dominant role in activating hut transcription. In succinate-depleted media, $\mathrm{CbrAB}$ activates hut transcription while derepressing the translation of hut mRNA mediated by the $\mathrm{Crc} / \mathrm{Hfq}$ complex, which is sequestrated by the CbrAB-activated ncRNAs ( $\mathrm{CrcY}$ and $\mathrm{CrcZ}$ ). Interestingly, deletions of $c b r A$ and $c b r B$ impaired swimming and swarming motility, decreased T3SS-associated genes expression, and enhanced the sensitivity to cold $[86,88]$. This indicated that the RpoN/CbrAB-CrcYZ$\mathrm{Crc} / \mathrm{Hfq}$ regulatory cascade system controls more important phenotypes beyond carbon and nitrogen assimilation.

In Xoo, transcriptome analysis revealed that both RpoN1 and RpoN2 regulate multiple genes involved in nitrogen and carbon metabolism. Deletion of rpoN1 significantly reduced bacterial growth in rich media M210. In rpoN1 and rpoN2 double mutants, severe inhibition of bacterial growth was observed compared to the rpoN1 mutant. Interestingly, the rpoN2 mutant growth was identical to the wild-type strain in rich medium M210 but decreased in plant-mimicking medium XOM2 [59,61]. These results suggested that both RpoN1 and RpoN2 are required for Xoo growth, and RpoN1 might complement the effect of RpoN2 on growth in rich media. PrpR, an EBP, was identified in Xoo, which is located the propionate catabolism operon and directly interacts with RpoN1 and RpoN2. The prpR deletion showed decreased Xoo growth in M210 media. In addition, RpoN1, RpoN2, and PrpR directly regulate numerous genes involved in the citric acid cycle (TCA cycle), such as prpB and $p r p C$, which encode methylisocitrate lyase and 2-methylcitrate synthase, respectively (data unpublished). The TCA cycle is a well-studied and important central pathway that connects almost all the individual metabolic pathways [89]. Therefore, RpoN1 and RpoN2 activated by PrpR may affect bacterial growth by regulating the TCA cycle in Xoo. However, unlike in Xoo, RpoN1 but not RpoN2 is essential for nitrogen assimilation and growth in $R$. solanacearum [63], and the EBP involved in the RpoN1-dependent regulation of the $R$. solanacearum remains unexplored.

\section{RpoN Regulates Virulence-Associated Phenotypes}

\subsection{T3SS}

T3SS is an essential virulence mechanism in bacteria; it has highly conserved structural components and participates in virulence by injecting the effector proteins into the cytosol of host cells [90-94]. The alternative sigma factor, HrpL, is the primary transcription factor that controls the expression of T3SS-associated genes [95]. In P. syringae, the hrpL expression requires HrpR and HrpS. It forms a heterodimer on the hrpL promoter and interacts with the RpoN-RNA polymerase holoenzyme to activate $h r p L$ transcription $[65,66]$. Unlike most EBPs, HrpR and HrpS contain the conserved AAA ${ }^{+}$domain and C-terminal DNA-binding domain but lack the N-terminal signal-sensing domain that functions in phosphorylation-dependent modulation of response regulator activity [72,96]. Previous studies have shown that HrpR and HrpS interact with RpoN via the conserved motifs of GAFTGA and GAYTGA, respectively [66]. In addition, constitutive expression of $h r p L$ in the individual $r p o N, h r p R$, and $h r p S$ mutants restored the transcription of $h r p$ genes to wildtype levels. Therefore, the RpoN-dependent cascade regulation of T3SS has proven that RpoN activates hrpL through HrpR and HrpS interaction, regulating hrp gene transcription in P. syringae. Interestingly, rpoN mutant cannot produce the phytotoxin coronatine, infect 
the host plant, or cause HR in the nonhost plant. Additionally, the constitutive expression of $h r p L$ in $r p o N$ mutant restored the HR to nonhost plants but did not restore coronatine production and growth $[73,97,98]$, indicating that the RpoN has both HrpL-dependent and -independent regulatory pathways in P. syringae.

Unlike in P. syringae, HrpS but not HrpR interacts with RpoN and activates $h r p L$, thus regulating the transcription of T3SS-associated genes in E. amylovora and D. dadantii [67-69]. Sequence analysis revealed that HrpS and RpoN contact the promoter sequence of $h r p L$ at the $-138 /-125$ (TGCAA-N 4 -TTGCA) and $-24 /-12$ (GG- N $_{10}$-TGC) regions, respectively [67]. Furthermore, a novel ribosome-associated protein, $\mathrm{YhbH}$, was identified. $\mathrm{YhbH}$ mediates HrpL-dependent T3SS regulation by modulating RpoN in E. amylovora. Individual deletions of $r p o N, h r p S, h r p L$, or $y h b H$ significantly decreased the transcription of T3SS genes, such as $h r p L, d s p E, h r p N$, and $h r p A$, and mutants failed to elicit hypersensitive response (HR) in tobacco. On the other hand, overexpression of hrpL by an inducible promoter rescued the T3SS gene expression and HR-eliciting ability in these mutants [76].

In addition, integration host factor (IHF), a nucleoid-associated protein, is often required to enhance the interaction between RpoN and EBP and for virulence by positively regulating the expressions of $h r p L$ and T3SS genes in E. amylovora [75]. HrpX/Y, a two-component system, is also involved in the RpoN-dependent regulation of T3SS by activating the $h r p L$ expression in D. dadantii [69]. In our previous study, we observed that RpoN2/FleQ positively regulates flagellin glycosylation, affecting the transcription of the T3SS genes in Xoo [77]. fliTX, a hypothetical protein gene, is located upstream to rpoN2, and regulated by RpoN2/FleQ and FliA in Xoo. fliTX deletion downregulated T3SS genes and attenuated induction of HR in tobacco [70]. These findings indicated that RpoN2 is dependent on FleQ to regulate T3SS genes in Xoo positively. However, either rpoN1 or $r p o N 2$ mutants induced a hypersensitive response in tobacco, which indicates that the $\sigma^{54}$ factor is not required for the functionality of the T3SS in R. solanacearum [63]. These studies revealed diversified regulatory effects of RpoN on T3SS in phytopathogenic bacteria.

\section{2. $T 4 P$}

The T4P, a special class of bacterial surface filament, plays a crucial role in surface adhesion, motility, biofilm formation, and virulence in bacteria [99-101]. More than 20 genes (named pilAX to pilZX) encoding T4P structural components and putative regulators were revealed in Xoo. PilRX, an EBP located in the T4P gene cluster, directly interacts with RpoN2 and regulates the T4P gene transcription, including the major pilin gene, pilAX, and the inner membrane platform protein gene, pilCX. Individual deletions of rpoN2, pilRX, pilAX, and pilCX resulted in significantly reduced twitching motility, biofilm formation, and virulence [62]. These findings suggest that the RpoN2/PilRX regulatory system controls bacterial motility and virulence by regulating T4P gene transcription in Xoo. The RpoN1 interaction with PilRX and its involvement in the regulation of T4P genes in Xoo remain unknown.

Unlike in Xoo, RpoN1 but not RpoN2 regulates the T4P synthesis and twitching motility in R. solanacearum [63]. The regulatory effect of RpoN1 on T4P genes depends on PehR, which is one of the EBPs and forms a two-component system with PehS. pehR deletion showed reduced bacterial swimming motility; however, the motility of the rpoN1 mutant was identical to that of the wild-type strain. Multiple studies have shown that PehSR regulates the fliC expression by regulating FlhDC, the primary regulator of flagellum synthesis, regulating swimming motility [102,103]. In addition, the regulator PhcA is involved in the swimming and twitching motility by negatively regulating the pehR expression [63,104]. These results indicated that both RpoN1 and PehR regulate T4P gene expression and twitching motility. Furthermore, PehR plays specific roles in controlling swimming motility in an RpoN1-independent manner in R. solanacearum. 


\subsection{Biofilm}

Biofilm is an important virulence-associated factor that promotes bacterial aggregation and surface attachment and protects bacteria from environmental stress, dehydration, and host immune responses [105-108]. The RpoN regulation in biofilm formation has been studied in Vibrio spp. As per the outcomes of this study, RpoN positively regulates biofilm formation in V. cholera [109], V. parahaemolyticus [110], V. anguillarum [23], and V. fischeri ESR1 [111], but negatively regulates biofilm formation in $V$. fischeri ES114 [112]. Interestingly, NtrC, one of the EBPs in V. cholera, inhibits biofilm formation by negatively regulating the expression of core regulator genes (vpsR, vpsT, and hapR) [113]. Furthermore, RpoN was shown to be unnecessary for the biofilm formation but essential for biofilm detachment in $V$. alginolyticus [114]. The positive regulation of RpoN in biofilm formation has been well studied in Lysobacter enzymogenes [115], Labrenzia aggregata [33], and P. fluorescens [116], but not in phytopathogenic bacteria. In our previous study, RpoN2 and PilRX promoted biofilm formation by regulating the T4P gene expression, thereby affecting virulence in Xoo [62]. Additionally, T4P is necessary for biofilm formation in other Xanthomonas spp., as demonstrated in previous studies $[117,118]$. These results indicated that the RpoN-dependent biofilm regulation pathway is a vital virulence regulation pathway in phytopathogenic bacteria.

\subsection{EPS}

EPSs are cell-associated or secreted outside the cell. They contain organic macromolecules, such as polysaccharides, proteins, and phospholipids in addition to some non-polymeric molecules $[119,120]$. They are microbial biopolymers produced under stress in harsh environments and nutrition-deprived conditions [121]. Therefore, EPS production is one of the strategies of bacteria to fight against biotic and abiotic stresses. Additionally, bacterial EPSs play essential roles in host-pathogen interactions, as well as biofilms [122]. In X. citri, VemR acts as a RpoN2 cognate activator [71], located in an operon flanked by fleQ and rpoN2. It encodes an atypical response regulator that contains only a receiver domain [123]. Deletion of the vemR gene resulted in a reduction in virulence and EPS production [71]. Moreover, VemR positively regulates flagellar biosynthesis by controlling the transcription of the rod gene flgG [71], but RpoN2- and VemR-mediated EPS production remains largely unknown.

\section{Conclusions and Future Perspectives}

$\mathrm{RpoN}$ is an important and conserved regulatory factor in a majority of phytopathogenic bacteria. Unlike other $\sigma$ factors, RpoN regulates the transcription of numerous functional genes in an EBP-dependent manner. On the basis of the number of $\sigma^{54}$ factors, we schematized the regulatory mechanism of RpoN in P. syringae and Xanthomonas species, which have single and double $\sigma^{54}$ factors, respectively (Figure 4). In P. syringae, a single RpoN along with HrpS and HrpR activates HrpL-dependent transcription of T3SS, subsequently regulating bacterial virulence. RpoN also regulates crcZX by binding to $\mathrm{CbrB}$, regulating nutritional metabolism and bacterial growth. In Xanthomonas, RpoN1 and RpoN2 have both unique and overlapping regulatory roles. RpoN2 regulates flagellum and T4P synthesis by interacting with FleQ and PilRX, respectively. RpoN2 also regulates the expression of fliTX and vemR to positively control bacterial virulence. Interestingly, both RpoN1 and RpoN2 interact with PrpR and control prpBC expression, thereby modulating the TCA cycle and bacterial growth. Moreover, RpoN1 indirectly regulates the transcription of RpoN2 with unknown EBP. 


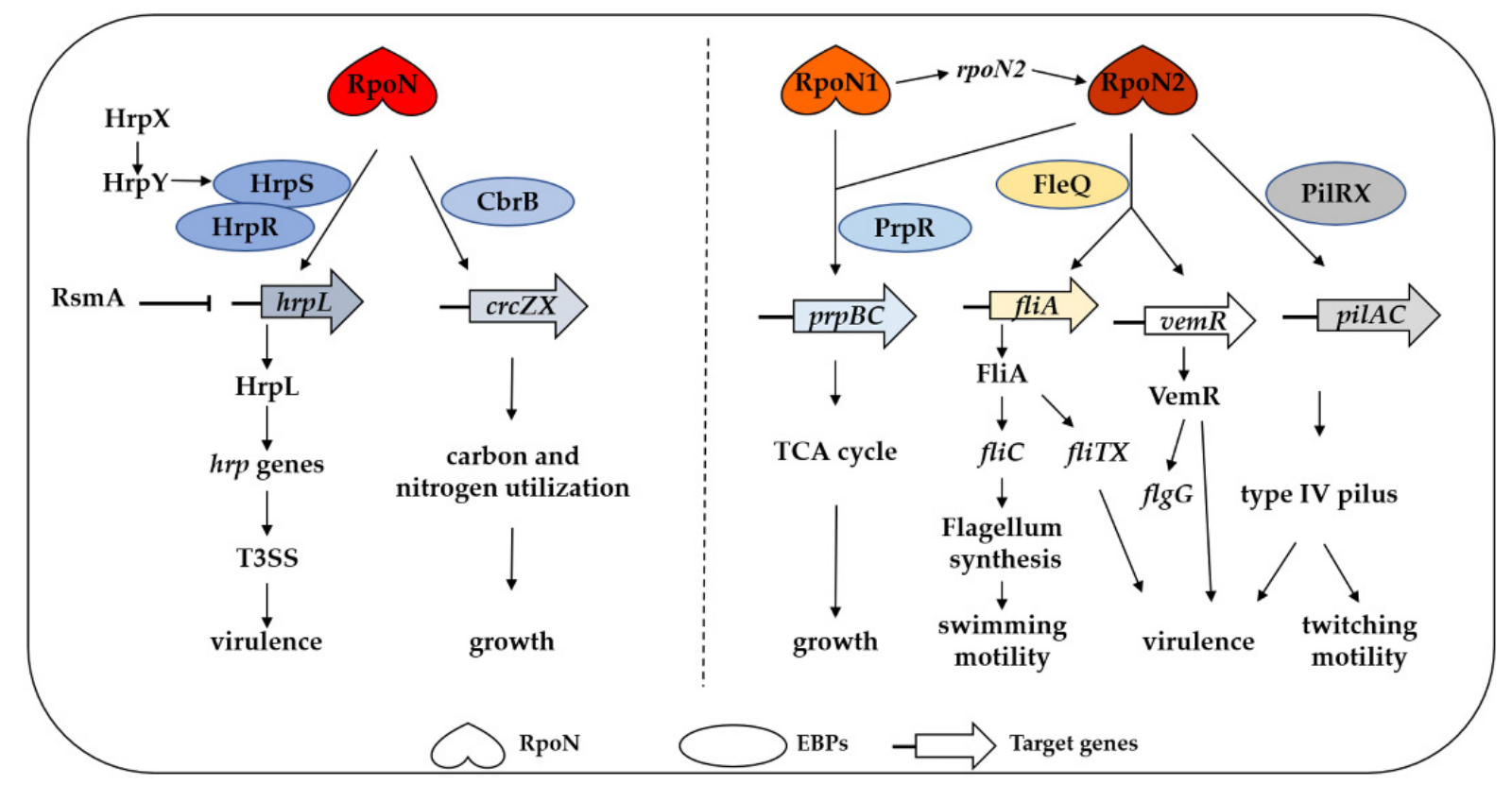

Figure 4. The regulatory functions of RpoN in major phytopathogenic bacteria. Left, P. syringae containing a single RpoN. RpoN requires HrpS and HrpR to activate HrpL-dependent transcription of T3SS, thereby regulating virulence. The two-component system HrpXY and RsmA is involved in the T3SS gene expression by positively regulating hrpS and negatively regulating $h r p L$. It also regulates $c r c Z X$ by binding with $\mathrm{CbrB}$ and regulates bacterial growth by affecting carbon and nitrogen utilization. Right, Xanthomonas containing two copies of RpoN factors, RpoN1 and RpoN2, with unique and overlapping regulatory roles. RpoN2 regulates the synthesis of flagellum and T4P by interacting with FleQ and PilRX, respectively. It also depends on FleQ to regulate the fliTX and vemR expression and positively regulate bacterial virulence. Both RpoN1 and RpoN2 are involved in the regulation of bacterial growth by interacting with PrpR. In addition, RpoN1, along with unknown EBP, indirectly regulates the RpoN2 transcription.

In the past few years, our understanding of $\sigma^{54}$-dependent transcription has significantly progressed owing to the structural analysis of the $\sigma^{54}$-RNAP complex and the application of transcriptome sequencing technology $[5,124,125]$. Concurrently, more and more $\sigma^{54}$-dependent EBPs and target genes have been identified using the bioinformatic method by analyzing the conserved $\mathrm{AAA}^{+}$domain and special binding sites $\mathrm{GGN}_{10} \mathrm{GC}$ on the promoter sequence, respectively [126-128]. However, whether these EPSs have redundant regulatory functions and how they competitively interact with $\sigma^{54}$ factors remain unknown. Furthermore, the upstream signals received by EBPs to activate $\sigma^{54}$-dependent regulatory pathways remain elusive. Our previous study identified the overlapping regulatory roles of two $\sigma^{54}$ factors in motility, virulence and growth, and identified three EBPs in Xoo. However, it is not yet known how the two $\sigma^{54}$ factors work together to regulate these pathways and which EBPs interact with $\sigma^{54}$ factors in these overlapping regulatory pathways. Therefore, to dissect the complex regulatory network of $\sigma^{54}$ in phytopathogenic bacteria, the following research-gaps should be addressed: (1) identification of candidate EBPs and characterization of their functions, (2) characterization of the interaction of EBPs with $\sigma^{54}$ factors, (3) clarification of the redundant or unique regulatory functions of EBPs, (4) identification of the upstream signals of $\sigma^{54}$ factors, and (5) identification of the conserved and specific regulatory pathways of $\sigma^{54}$ factors in different phytopathogenic bacteria.

Author Contributions: Writing-original draft preparation, C.Y. and D.X.; writing-review and editing, F.Y., X.W., and H.C.; supervision, H.C. All authors read and agreed to the published version of the manuscript.

Funding: This work was supported by grants from the National Natural Science Foundation of China (31600105 to C. Yu; 31870120 to C. He; 31972255 to H. Chen). 
Institutional Review Board Statement: Not applicable.

Informed Consent Statement: Not applicable.

Data Availability Statement: Not applicable.

Acknowledgments: We apologize to the authors whose relevant work on sigma(54)/RpoN in phytopathogenic bacteria has not been cited owing to length constraints.

Conflicts of Interest: The authors declare no conflict of interest.

\section{References}

1. De Dios, R.; Santero, E.; Reyes-Ramirez, F. Extracytoplasmic function sigma factors as tools for coordinating stress responses. Int. J. Mol. Sci. 2021, 22, 3900. [CrossRef]

2. Borukhov, S.; Nudler, E. RNA polymerase holoenzyme: Structure, function and biological implications. Curr. Opin. Microbiol. 2003, 6, 93-100. [CrossRef]

3. Davis, M.C.; Kesthely, C.A.; Franklin, E.A.; MacLellan, S.R. The essential activities of the bacterial sigma factor. Can. J. Microbiol. 2017, 63, 89-99. [CrossRef]

4. Zhang, N.; Darbari, V.C.; Glyde, R.; Zhang, X.; Buck, M. The bacterial enhancer-dependent RNA polymerase. Biochem. J. 2016, 473, 3741-3753. [CrossRef]

5. Yang, Y.; Darbari, V.C.; Zhang, N.; Lu, D.; Glyde, R.; Wang, Y.P.; Winkelman, J.T.; Gourse, R.L.; Murakami, K.S.; Buck, M.; et al. Transcription. Structures of the RNA polymerase-sigma54 reveal new and conserved regulatory strategies. Science 2015, 349, 882-885. [CrossRef]

6. Danson, A.E.; Jovanovic, M.; Buck, M.; Zhang, X. Mechanisms of sigma(54)-dependent transcription initiation and regulation. J Mol. Biol. 2019, 431, 3960-3974. [CrossRef] [PubMed]

7. Schulz, S.; Eckweiler, D.; Bielecka, A.; Nicolai, T.; Franke, R.; Dotsch, A.; Hornischer, K.; Bruchmann, S.; Duvel, J.; Haussler, S. Elucidation of sigma factor-associated networks in Pseudomonas aeruginosa reveals a modular architecture with limited and function-specific crosstalk. PLoS Pathog. 2015, 11, e1004744. [CrossRef] [PubMed]

8. Lloyd, M.G.; Vossler, J.L.; Nomura, C.T.; Moffat, J.F. Blocking RpoN reduces virulence of Pseudomonas aeruginosa isolated from cystic fibrosis patients and increases antibiotic sensitivity in a laboratory strain. Sci. Rep. 2019, 9, 6677. [CrossRef]

9. Lundgren, B.R.; Shoytush, J.M.; Scheel, R.A.; Sain, S.; Sarwar, Z.; Nomura, C.T. Utilization of L-glutamate as a preferred or sole nutrient in Pseudomonas aeruginosa PAO1 depends on genes encoding for the enhancer-binding protein AauR, the sigma factor RpoN and the transporter complex AatJQMP. BMC Microbiol. 2021, 21, 83. [CrossRef] [PubMed]

10. Hall, C.W.; Farkas, E.; Zhang, L.; Mah, T.F. Potentiation of aminoglycoside lethality by C-4-dicarboxylates requires RpoN in antibiotic-tolerant Pseudomonas aeruginosa. Antimicrob. Agents Chemother. 2019, 63, e01313-19. [CrossRef]

11. Viducic, D.; Murakami, K.; Amoh, T.; Ono, T.; Miyake, Y. RpoN promotes Pseudomonas aeruginosa survival in the presence of tobramycin. Front. Microbiol. 2017, 8, 839. [CrossRef]

12. Viducic, D.; Murakami, K.; Amoh, T.; Ono, T.; Miyake, Y. RpoN modulates carbapenem tolerance in Pseudomonas aeruginosa through Pseudomonas quinolone signal and PqsE. Antimicrob. Agents Chemother. 2016, 60, 5752-5764. [CrossRef]

13. Shao, X.; Zhang, X.; Zhang, Y.; Zhu, M.; Yang, P.; Yuan, J.; Xie, Y.; Zhou, T.; Wang, W.; Chen, S.; et al. RpoN-dependent direct regulation of quorum sensing and the type VI secretion system in Pseudomonas aeruginosa PAO1. J. Bacteriol. 2018, 200, e00205-18. [CrossRef]

14. Viducic, D.; Ono, T.; Murakami, K.; Katakami, M.; Susilowati, H.; Miyake, Y. RpoN gene of Pseudomonas aeruginosa alters its susceptibility to quinolones and carbapenems. Antimicrob. Agents Chemother. 2007, 51, 1455-1462. [CrossRef]

15. Herrera, M.C.; Duque, E.; Rodriguez-Herva, J.J.; Fernandez-Escamilla, A.M.; Ramos, J.L. Identification and characterization of the PhhR regulon in Pseudomonas putida. Environ. Microbiol. 2010, 12, 1427-1438. [PubMed]

16. Dvorak, P.; Alvarez-Carreno, C.; Ciordia, S.; Paradela, A.; de Lorenzo, V. An updated structural model of the A domain of the Pseudomonas putida XylR regulator poses an atypical interplay with aromatic effectors. Environ. Microbiol. 2021, 23, $4418-4433$. [CrossRef] [PubMed]

17. Bittner, M.; Saldias, S.; Altamirano, F.; Valvano, M.A.; Contreras, I. RpoS and RpoN are involved in the growth-dependent regulation of $r f a H$ transcription and $\mathrm{O}$ antigen expression in Salmonella enterica serovar Typhi. Microb. Pathog. 2004, 36, 19-24. [CrossRef] [PubMed]

18. Wang, K.; Liu, E.; Song, S.; Wang, X.; Zhu, Y.; Ye, J.; Zhang, H. Characterization of Edwardsiella tarda rpoN: Roles in sigma(70) family regulation, growth, stress adaption and virulence toward fish. Arch. Microbiol. 2012, 194, 493-504. [CrossRef]

19. Zhu, L.; Gong, T.; Wood, T.L.; Yamasaki, R.; Wood, T.K. Sigma54 -dependent regulator DVU2956 switches Desulfovibrio vulgaris from biofilm formation to planktonic growth and regulates hydrogen sulfide production. Environ. Microbiol. 2019, 21, 3564-3576. [CrossRef]

20. Zhao, K.; Liu, M.; Burgess, R.R. Promoter and regulon analysis of nitrogen assimilation factor, sigma54, reveal alternative strategy for E. coli MG1655 flagellar biosynthesis. Nucleic Acids Res. 2010, 38, 1273-1283. [CrossRef]

21. Reitzer, L.; Schneider, B.L. Metabolic context and possible physiological themes of sigma(54)-dependent genes in Escherichia coli. Microbiol. Mol. Biol. Rev. 2001, 65, 422-444. [CrossRef] 
22. Schulz, T.; Rydzewski, K.; Schunder, E.; Holland, G.; Bannert, N.; Heuner, K. FliA expression analysis and influence of the regulatory proteins RpoN, FleQ and FliA on virulence and in vivo fitness in Legionella pneumophila. Arch. Microbiol. 2012, 194, 977-989. [CrossRef] [PubMed]

23. Hao, B.; Mo, Z.L.; Xiao, P.; Pan, H.J.; Lan, X.; Li, G.Y. Role of alternative sigma factor 54 (RpoN) from Vibrio anguillarum M3 in protease secretion, exopolysaccharide production, biofilm formation, and virulence. Appl. Microbiol. Biotechnol. 2013, 97, 2575-2585. [CrossRef] [PubMed]

24. Shang, L.; Yan, Y.; Zhan, Y.; Ke, X.; Shao, Y.; Liu, Y.; Yang, H.; Wang, S.; Dai, S.; Lu, J.; et al. A regulatory network involving Rpo, Gac and Rsm for nitrogen-fixing biofilm formation by Pseudomonas stutzeri. NPJ Biofilms Microbiomes 2021, 7, 54. [CrossRef] [PubMed]

25. Cai, Z.; Liu, Y.; Chen, Y.; Yam, J.K.; Chew, S.C.; Chua, S.L.; Wang, K.; Givskov, M.; Yang, L. RpoN regulates virulence factors of Pseudomonas aeruginosa via modulating the PqsR quorum sensing regulator. Int. J. Mol. Sci. 2015, 16, 28311-28319. [CrossRef]

26. Tague, J.G.; Hong, J.; Kalburge, S.S.; Boyd, E.F. Regulatory small RNA, Qrr2 is expressed independently of sigma factor-54 and can function as the sole Qrr sRNA to control quorum sensing in Vibrio parahaemolyticus. J. Bacteriol. 2021, JB0035021. [CrossRef]

27. Dong, T.G.; Mekalanos, J.J. Characterization of the RpoN regulon reveals differential regulation of T6SS and new flagellar operons in Vibrio cholerae O37 strain V52. Nucleic Acids Res. 2012, 40, 7766-7775. [CrossRef]

28. Wang, Y.Z.; Li, Y.; Wang, J.L.; Wang, X.Y. FleQ regulates both the type VI secretion system and flagella in Pseudomonas putida. Biotechnol. Appl. Biochem. 2018, 65, 419-427. [CrossRef]

29. Mahmud, A.; Nilsson, K.; Fahlgren, A.; Navais, R.; Choudhury, R.; Avican, K.; Fallman, M. Genome-scale mapping reveals complex regulatory activities of RpoN in Yersinia pseudotuberculosis. mSystems 2020, 5, e01006-20. [CrossRef]

30. Arnold, W.K.; Savage, C.R.; Lethbridge, K.G.; Smith, T.C., 2nd; Brissette, C.A.; Seshu, J.; Stevenson, B. Transcriptomic insights on the virulence-controlling CsrA, BadR, RpoN, and RpoS regulatory networks in the Lyme disease spirochete. PLoS ONE 2018, 13, e0203286. [CrossRef]

31. Feng, L.; Bi, W.; Chen, S.; Zhu, J.; Liu, X. Regulatory function of sigma factors RpoS/RpoN in adaptation and spoilage potential of Shewanella baltica. Food Microbiol. 2021, 97, 103755. [CrossRef] [PubMed]

32. Zhang, J.J.; Hu, W.L.; Yang, Y.Y.; Li, H.X.; Picardeau, M.; Yan, J.; Yang, X.F. The sigma factor sigma(54) is required for the long-term survival of Leptospira biflexa in water. Mol. Microbiol. 2018, 109, 63-77. [CrossRef] [PubMed]

33. Xu, T.; Yu, M.; Liu, J.; Lin, H.; Liang, J.; Zhang, X.H. Role of RpoN from Labrenzia aggregata LZB033 (Rhodobacteraceae) in formation of flagella and biofilms, motility, and environmental adaptation. Appl. Environ. Microbiol. 2019, 85, e02844-18. [CrossRef]

34. Sapi, E.; Theophilus, P.A.; Pham, T.V.; Burugu, D.; Luecke, D.F. Effect of RpoN, RpoS and LuxS pathways on the biofilm formation and antibiotic sensitivity of Borrelia burgdorferi. Eur. J. Microbiol. Immunol. 2016, 6, 272-286. [CrossRef] [PubMed]

35. Gao, F.; Danson, A.E.; Ye, F.Z.; Jovanovic, M.; Buck, M.; Zhang, X.D. Bacterial enhancer binding proteins-AAA(+) proteins in transcription activation. Biomolecules 2020, 10, 351. [CrossRef]

36. Studholme, D.J.; Dixon, R. Domain architectures of sigma54-dependent transcriptional activators. J. Bacteriol. 2003, 185, 1757-1767. [CrossRef]

37. Schumacher, J.; Joly, N.; Rappas, M.; Zhang, X.; Buck, M. Structures and organisation of AAA+ enhancer binding proteins in transcriptional activation. J. Struct. Biol. 2006, 156, 190-199. [CrossRef]

38. Schaefer, J.; Engl, C.; Zhang, N.; Lawton, E.; Buck, M. Genome wide interactions of wild-type and activator bypass forms of sigma54. Nucleic Acids Res. 2015, 43, 7280-7291. [CrossRef]

39. Ghosh, T.; Bose, D.; Zhang, X. Mechanisms for activating bacterial RNA polymerase. FEMS Microbiol. Rev. 2010, 34, 611-627. [CrossRef]

40. Lundgren, B.R.; Bailey, F.J.; Moley, G.; Nomura, C.T. DdaR (PA1196) regulates expression of dimethylarginine dimethylaminohydrolase for the metabolism of methylarginines in Pseudomonas aeruginosa PAO1. J. Bacteriol. 2017, 199, e00001-17. [CrossRef]

41. Lundgren, B.R.; Villegas-Penaranda, L.R.; Harris, J.R.; Mottern, A.M.; Dunn, D.M.; Boddy, C.N.; Nomura, C.T. Genetic analysis of the assimilation of $\mathrm{C}_{5}$-dicarboxylic acids in Pseudomonas aeruginosa PAO1. J. Bacteriol. 2014, 196, 2543-2551. [CrossRef]

42. Lundgren, B.R.; Sarwar, Z.; Pinto, A.; Ganley, J.G.; Nomura, C.T. Ethanolamine catabolism in Pseudomonas aeruginosa PAO1 is regulated by the enhancer-binding protein EatR (PA4021) and the alternative sigma factor RpoN. J. Bacteriol. 2016, 198, 2318-2329. [CrossRef] [PubMed]

43. Lundgren, B.R.; Harris, J.R.; Sarwar, Z.; Scheel, R.A.; Nomura, C.T. The metabolism of (R)-3-hydroxybutyrate is regulated by the enhancer-binding protein PA2005 and the alternative sigma factor RpoN in Pseudomonas aeruginosa PAO1. Microbiology 2015, 161, 2232-2242. [CrossRef]

44. Sarwar, Z.; Lundgren, B.R.; Grassa, M.T.; Wang, M.X.; Gribble, M.; Moffat, J.F.; Nomura, C.T. GcsR, a TyrR-like enhancerbinding protein, regulates expression of the glycine cleavage system in Pseudomonas aeruginosa PAO1. Msphere 2016, 1, e00020-16. [CrossRef] [PubMed]

45. Lundgren, B.R.; Thornton, W.; Dornan, M.H.; Villegas-Penaranda, L.R.; Boddy, C.N.; Nomura, C.T. Gene PA2449 is essential for glycine metabolism and pyocyanin biosynthesis in Pseudomonas aeruginosa PAO1. J. Bacteriol. 2013, 195, 2087-2100. [CrossRef]

46. Baraquet, C.; Murakami, K.; Parsek, M.R.; Harwood, C.S. The FleQ protein from Pseudomonas aeruginosa functions as both a repressor and an activator to control gene expression from the pel operon promoter in response to c-di-GMP. Nucleic Acids Res. 2012, 40, 7207-7218. [CrossRef] [PubMed] 
47. Baraquet, C.; Harwood, C.S. Cyclic diguanosine monophosphate represses bacterial flagella synthesis by interacting with the Walker A motif of the enhancer-binding protein FleQ. Proc. Natl. Acad. Sci. USA 2013, 110, 18478-18483. [CrossRef]

48. Koskenkorva, T.; Aro-Karkkainen, N.; Bachmann, D.; Arai, H.; Frey, A.D.; Kallio, P.T. Transcriptional activity of Pseudomonas aeruginosa fhp promoter is dependent on two regulators in addition to FhpR. Arch. Microbiol. 2008, 189, 385-396. [CrossRef]

49. Koskenkorva-Frank, T.S.; Kallio, P.T. Induction of Pseudomonas aeruginosa fhp and fhpR by reactive oxygen species. Can. J. Microbiol. 2009, 55, 657-663. [CrossRef]

50. Hampel, K.J.; LaBauve, A.E.; Meadows, J.A.; Fitzsimmons, L.F.; Nock, A.M.; Wargo, M.J. Characterization of the GbdR regulon in Pseudomonas aeruginosa. J. Bacteriol. 2014, 196, 7-15. [CrossRef]

51. Sanchez, D.G.; Primo, E.D.; Damiani, M.T.; Lisa, A.T. Pseudomonas aeruginosa gbdR gene is transcribed from a sigma54-dependent promoter under the control of NtrC/CbrB, IHF and BetI. Microbiology 2017, 163, 1343-1354. [CrossRef] [PubMed]

52. Studholme, D.J.; Buck, M. The biology of enhancer-dependent transcriptional regulation in bacteria: Insights from genome sequences. FEMS Microbiol. Lett. 2000, 186, 1-9. [CrossRef]

53. Bush, M.; Dixon, R. The role of bacterial enhancer binding proteins as specialized activators of sigma(54)-dependent transcription. Microbiol. Mol. Biol. R 2012, 76, 497-529. [CrossRef] [PubMed]

54. Mansfield, J.; Genin, S.; Magori, S.; Citovsky, V.; Sriariyanum, M.; Ronald, P.; Dow, M.A.X.; Verdier, V.; Beer, S.V.; Machado, M.A.; et al. Top 10 plant pathogenic bacteria in molecular plant pathology. Mol. Plant Pathol. 2012, 13, 614629. [CrossRef]

55. Casaz, P.; Gallegos, M.T.; Buck, M. Systematic analysis of sigma54 N-terminal sequences identifies regions involved in positive and negative regulation of transcription. J. Mol. Biol. 1999, 292, 229-239. [CrossRef]

56. Hong, E.; Doucleff, M.; Wemmer, D.E. Structure of the RNA polymerase core-binding domain of sigma(54) reveals a likely conformational fracture point. J. Mol. Biol. 2009, 390, 70-82. [CrossRef]

57. Yang, T.C.; Leu, Y.W.; Chang-Chien, H.C.; Hu, R.M. Flagellar biogenesis of Xanthomonas campestris requires the alternative sigma factors RpoN2 and FliA and is temporally regulated by FlhA, FlhB, and FlgM. J. Bacteriol. 2009, 191, 2266-2275. [CrossRef]

58. Li, K.; Wu, G.; Liao, Y.; Zeng, Q.; Wang, H.; Liu, F. RpoN1 and RpoN2 play different regulatory roles in virulence traits, flagellar biosynthesis, and basal metabolism in Xanthomonas campestris. Mol. Plant Pathol. 2020, 21, 907-922. [CrossRef] [PubMed]

59. Yu, C.; Nguyen, D.P.; Yang, F.; Shi, J.; Wei, Y.; Tian, F.; Zhao, X.; Chen, H. Transcriptome analysis revealed overlapping and special regulatory roles of RpoN1 and RpoN2 in motility, virulence, and growth of Xanthomonas oryzae pv. oryzae. Front. Microbiol. 2021, 12, 653354. [CrossRef] [PubMed]

60. Gicharu, G.K.; Sun, D.L.; Hu, X.; Fan, X.J.; Zhuo, T.; Wu, C.W.; Zou, H.S. The sigma 54 genes rpoN1 and rpoN2 of Xanthomonas citri subsp citri play different roles in virulence, nutrient utilization and cell motility. J. Integr. Agric. 2016, 15, 2032-2039. [CrossRef]

61. Tian, F.; Yu, C.; Li, H.; Wu, X.; Li, B.; Chen, H.; Wu, M.; He, C. Alternative sigma factor RpoN2 is required for flagellar motility and full virulence of Xanthomonas oryzae pv. oryzae. Microbiol. Res. 2015, 170, 177-183. [CrossRef]

62. Yu, C.; Nguyen, D.P.; Ren, Z.; Liu, J.; Yang, F.; Tian, F.; Fan, S.; Chen, H. The RpoN2-PilRX regulatory system governs type IV pilus gene transcription and is required for bacterial motility and virulence in Xanthomonas oryzae pv. oryzae. Mol. Plant Pathol. 2020, 21, 652-666. [CrossRef] [PubMed]

63. Ray, S.K.; Kumar, R.; Peeters, N.; Boucher, C.; Genin, S. RpoN1, but not RpoN2, is required for twitching motility, natural competence, growth on nitrate, and virulence of Ralstonia solanacearum. Front. Microbiol. 2015, 6, 229. [CrossRef]

64. Lundgren, B.R.; Connolly, M.P.; Choudhary, P.; Brookins-Little, T.S.; Chatterjee, S.; Raina, R.; Nomura, C.T. Defining the metabolic functions and roles in virulence of the rpoN1 and rpoN2 genes in Ralstonia solanacearum GMI1000. PLoS ONE 2015, 10, e0144852.

65. Hutcheson, S.W.; Bretz, J.; Sussan, T.; Jin, S.; Pak, K. Enhancer-binding proteins HrpR and HrpS interact to regulate hrp-encoded type III protein secretion in Pseudomonas syringae strains. J. Bacteriol. 2001, 183, 5589-5598. [CrossRef] [PubMed]

66. Jovanovic, M.; James, E.H.; Burrows, P.C.; Rego, F.G.; Buck, M.; Schumacher, J. Regulation of the co-evolved HrpR and HrpS AAA+ proteins required for Pseudomonas syringae pathogenicity. Nat. Commun. 2011, 2, 177. [CrossRef]

67. Lee, J.H.; Sundin, G.W.; Zhao, Y. Identification of the HrpS binding site in the hrpL promoter and effect of the RpoN binding site of HrpS on the regulation of the type III secretion system in Erwinia amylovora. Mol. Plant Pathol. 2016, 17, 691-702. [CrossRef]

68. Ramos, L.S.; Lehman, B.L.; Sinn, J.P.; Pfeufer, E.E.; Halbrendt, N.O.; McNellis, T.W. The fire blight pathogen Erwinia amylovora requires the rpoN gene for pathogenicity in apple. Mol. Plant Pathol. 2013, 14, 838-843. [CrossRef]

69. Yi, X.; Yamazaki, A.; Biddle, E.; Zeng, Q.; Yang, C.H. Genetic analysis of two phosphodiesterases reveals cyclic diguanylate regulation of virulence factors in Dickeya dadantii. Mol. Microbiol. 2010, 77, 787-800. [CrossRef]

70. Yu, C.; Chen, H.; Tian, F.; Yang, F.; He, C. RpoN2- and FliA-regulated fliTX is indispensible for flagellar motility and virulence in Xanthomonas oryzae pv. oryzae. BMC Microbiol. 2017, 17, 171. [CrossRef]

71. Wu, W.; Zhao, Z.; Luo, X.; Fan, X.; Zhuo, T.; Hu, X.; Liu, J.; Zou, H. Response regulator VemR regulates the transcription of flagellar rod gene flgG by interacting with sigma(54) factor RpoN2 in Xanthomonas citri ssp. citri. Mol. Plant Pathol. 2019, 20, 372-381. [CrossRef]

72. Tang, X.; Xiao, Y.; Zhou, J.M. Regulation of the type III secretion system in phytopathogenic bacteria. Mol. Plant Microbe Interact. 2006, 19, 1159-1166. [CrossRef] [PubMed]

73. Alarcon-Chaidez, F.J; Keith, L.; Zhao, Y.; Bender, C.L. RpoN (sigma(54)) is required for plasmid-encoded coronatine biosynthesis in Pseudomonas syringae. Plasmid 2003, 49, 106-117. [CrossRef] 
74. Filiatrault, M.J.; Stodghill, P.V.; Wilson, J.; Butcher, B.G.; Chen, H.; Myers, C.R.; Cartinhour, S.W. CrcZ and CrcX regulate carbon source utilization in Pseudomonas syringae pathovar tomato strain DC3000. RNA Biol. 2013, 10, 245-255. [CrossRef]

75. Lee, J.H.; Zhao, Y. Integration host factor is required for RpoN-dependent $h r p L$ gene expression and controls motility by positively regulating rsmB sRNA in Erwinia amylovora. Phytopathology 2016, 106, 29-36. [CrossRef]

76. Ancona, V.; Li, W.; Zhao, Y. Alternative sigma factor RpoN and its modulation protein YhbH are indispensable for Erwinia amylovora virulence. Mol. Plant Pathol. 2014, 15, 58-66. [CrossRef] [PubMed]

77. Yu, C.; Chen, H.; Tian, F.; Yang, F.; Yuan, X.; Yang, C.H.; He, C. A ten gene-containing genomic island determines flagellin glycosylation: Implication for its regulatory role in motility and virulence of Xanthomonas oryzae pv. oryzae. Mol. Plant Pathol. 2018, 19, 579-592. [CrossRef]

78. Filiatrault, M.J.; Stodghill, P.V.; Bronstein, P.A.; Moll, S.; Lindeberg, M.; Grills, G.; Schweitzer, P.; Wang, W.; Schroth, G.P.; Luo, S.; et al. Transcriptome analysis of Pseudomonas syringae identifies new genes, noncoding RNAs, and antisense activity. $J$. Bacteriol. 2010, 192, 2359-2372. [CrossRef] [PubMed]

79. Nishijyo, T.; Haas, D.; Itoh, Y. The CbrA-CbrB two-component regulatory system controls the utilization of multiple carbon and nitrogen sources in Pseudomonas aeruginosa. Mol. Microbiol. 2001, 40, 917-931. [CrossRef] [PubMed]

80. Abdou, L.; Chou, H.T.; Haas, D.; Lu, C.D. Promoter recognition and activation by the global response regulator CbrB in Pseudomonas aeruginosa. J. Bacteriol. 2011, 193, 2784-2792. [CrossRef]

81. Barroso, R.; Garcia-Maurino, S.M.; Tomas-Gallardo, L.; Andujar, E.; Perez-Alegre, M.; Santero, E.; Canosa, I. The CbrB regulon: Promoter dissection reveals novel insights into the CbrAB expression network in Pseudomonas putida. PLoS ONE 2018, 13, e0209191. [CrossRef] [PubMed]

82. Wirtz, L.; Eder, M.; Schipper, K.; Rohrer, S.; Jung, H. Transport and kinase activities of CbrA of Pseudomonas putida KT2440. Sci. Rep. 2020, 10, 5400. [CrossRef] [PubMed]

83. Martinez-Valenzuela, M.; Guzman, J.; Moreno, S.; Ahumada-Manuel, C.L.; Espin, G.; Nunez, C. Expression of the sRNAs CrcZ and $\mathrm{CrcY}$ modulate the strength of carbon catabolite repression under diazotrophic or non-diazotrophic growing conditions in Azotobacter vinelandii. PLoS ONE 2018, 13, e0208975. [CrossRef] [PubMed]

84. Quiroz-Rocha, E.; Moreno, R.; Hernandez-Ortiz, A.; Fragoso-Jimenez, J.C.; Muriel-Millan, L.F.; Guzman, J.; Espin, G.; Rojo, F.; Nunez, C. Glucose uptake in Azotobacter vinelandii occurs through a GluP transporter that is under the control of the CbrA/CbrB and Hfq-Crc systems. Sci. Rep. 2017, 7, 858. [CrossRef]

85. Quiroz-Rocha, E.; Bonilla-Badia, F.; Garcia-Aguilar, V.; Lopez-Pliego, L.; Serrano-Roman, J.; Cocotl-Yanez, M.; Guzman, J.; Ahumada-Manuel, C.L.; Muriel-Millan, L.F.; Castaneda, M.; et al. Two-component system CbrA/CbrB controls alginate production in Azotobacter vinelandii. Microbiology 2017, 163, 1105-1115. [CrossRef]

86. Dethlefsen, S.; Jager, C.; Klockgether, J.; Schomburg, D.; Tummler, B. Metabolite profiling of the cold adaptation of Pseudomonas putida KT2440 and cold-sensitive mutants. Environ. Microbiol. Rep. 2019, 11, 777-783. [CrossRef]

87. Naren, N.; Zhang, X.X. Role of a local transcription factor in governing cellular carbon/nitrogen homeostasis in Pseudomonas fluorescens. Nucleic Acids Res. 2021, 49, 3204-3216. [CrossRef]

88. Sivakumar, R.; Gunasekaran, P.; Rajendhran, J. Inactivation of CbrAB two-component system hampers root colonization in rhizospheric strain of Pseudomonas aeruginosa PGPR2. Biochim. Biophys. Acta Gene Regul. Mech. 2021, 1864, 194763. [CrossRef]

89. Akram, M. Citric acid cycle and role of its intermediates in metabolism. Cell Biochem. Biophys. 2014, 68, 475-478. [CrossRef]

90. O'Malley, M.R.; Anderson, J.C. Regulation of the Pseudomonas syringae type III secretion system by host environment signals. Microorganisms 2021, 9, 1227. [CrossRef]

91. Slater, S.L.; Sagfors, A.M.; Pollard, D.J.; Ruano-Gallego, D.; Frankel, G. The type III secretion system of pathogenic Escherichia coli. Curr. Top. Microbiol. Immunol. 2018, 416, 51-72.

92. Pinaud, L.; Sansonetti, P.J.; Phalipon, A. Host cell targeting by enteropathogenic bacteria T3SS effectors. Trends Microbiol. 2018, 26, 266-283. [CrossRef]

93. Bajunaid, W.; Haidar-Ahmad, N.; Kottarampatel, A.H.; Ourida Manigat, F.; Silue, N.; Tchagang, C.F.; Tomaro, K.; Campbell-Valois, F.X. The T3SS of Shigella: Expression, structure, function, and role in Vacuole fscape. Microorganisms 2020, 8, 1933. [CrossRef]

94. Sanchez-Garrido, J.; Alberdi, L.; Chatterjee, S.; Frankel, G.; Mullineaux-Sanders, C. Type III secretion system effector subnetworks elicit distinct host immune responses to infection. Curr. Opin. Microbiol. 2021, 64, 19-26. [CrossRef]

95. Xiao, Y.; Hutcheson, S.W. A single promoter sequence recognized by a newly identified alternate sigma factor directs expression of pathogenicity and host range determinants in Pseudomonas syringae. J. Bacteriol. 1994, 176, 3089-3091. [CrossRef]

96. Shingler, V. Signal sensing by sigma(54)-dependent regulators: Derepression as a control mechanism. Mol. Microbiol. 1996, 19, 409-416. [CrossRef]

97. Hendrickson, E.L.; Guevera, P.; Ausubel, F.M. The alternative sigma factor RpoN is required for hrp activity in Pseudomonas syringae pv. maculicola and acts at the level of hrpL transcription. J. Bacteriol. 2000, 182, 3508-3516.

98. Kazmierczak, M.J.; Wiedmann, M.; Boor, K.J. Alternative sigma factors and their roles in bacterial virulence. Microbiol. Mol. Biol. Rev. 2005, 69, 527-543. [CrossRef] [PubMed]

99. Craig, L.; Forest, K.T.; Maier, B. Type IV pili: Dynamics, biophysics and functional consequences. Nat. Rev. Microbiol. 2019, 17, 429-440. [CrossRef] [PubMed]

100. Wang, F.; Baquero, D.P.; Su, Z.; Beltran, L.C.; Prangishvili, D.; Krupovic, M.; Egelman, E.H. The structures of two archaeal type IV pili illuminate evolutionary relationships. Nat. Commun. 2020, 11, 3424. [CrossRef] [PubMed] 
101. Muschiol, S.; Aschtgen, M.S.; Nannapaneni, P.; Henriques-Normark, B. Gram-positive type IV pili and competence. Microbiol. Spectr. 2019, 7. [CrossRef] [PubMed]

102. Allen, C.; Gay, J.; Simon-Buela, L. A regulatory locus, pehSR, controls polygalacturonase production and other virulence functions in Ralstonia solanacearum. Mol. Plant Microbe Interact. 1997, 10, 1054-1064. [CrossRef] [PubMed]

103. Tans-Kersten, J.; Brown, D.; Allen, C. Swimming motility, a virulence trait of Ralstonia solanacearum, is regulated by FlhDC and the plant host environment. Mol. Plant Microbe Interact. 2004, 17, 686-695. [CrossRef]

104. Liu, H.; Kang, Y.; Genin, S.; Schell, M.A.; Denny, T.P. Twitching motility of Ralstonia solanacearum requires a type IV pilus system. Microbiology 2001, 147, 3215-3229. [CrossRef]

105. Cugini, C.; Shanmugam, M.; Landge, N.; Ramasubbu, N. The role of exopolysaccharides in oral biofilms. J. Dent. Res. 2019, 98, 739-745. [CrossRef]

106. Vestby, L.K.; Gronseth, T.; Simm, R.; Nesse, L.L. Bacterial biofilm and its role in the pathogenesis of disease. Antibiotics 2020, 9 , 59. [CrossRef]

107. Rather, M.A.; Gupta, K.; Mandal, M. Microbial biofilm: Formation, architecture, antibiotic resistance, and control strategies. Braz. J. Microbiol. 2021, 52, 1701-1718. [CrossRef]

108. Ruhal, R.; Kataria, R. Biofilm patterns in gram-positive and gram-negative bacteria. Microbiol. Res. 2021, 251, 126829. [CrossRef] [PubMed]

109. Yildiz, F.H.; Liu, X.S.; Heydorn, A.; Schoolnik, G.K. Molecular analysis of rugosity in a Vibrio cholerae O1 El Tor phase variant. Mol. Microbiol. 2004, 53, 497-515. [CrossRef]

110. Whitaker, W.B.; Richards, G.P.; Boyd, E.F. Loss of sigma factor RpoN increases intestinal colonization of Vibrio parahaemolyticus in an adult mouse model. Infect. Immun. 2014, 82, 544-556. [CrossRef]

111. Yip, E.S.; Grublesky, B.T.; Hussa, E.A.; Visick, K.L. A novel, conserved cluster of genes promotes symbiotic colonization and sigma-dependent biofilm formation by Vibrio fischeri. Mol. Microbiol. 2005, 57, 1485-1498. [CrossRef]

112. Wolfe, A.J.; Millikan, D.S.; Campbell, J.M.; Visick, K.L. Vibrio fischeri sigma54 controls motility, biofilm formation, luminescence, and colonization. Appl. Environ. Microbiol. 2004, 70, 2520-2524. [CrossRef] [PubMed]

113. Cheng, A.T.; Zamorano-Sanchez, D.; Teschler, J.K.; Wu, D.; Yildiz, F.H. NtrC adds a new node to the complex regulatory network of biofilm formation and vps expression in Vibrio cholerae. J. Bacteriol. 2018, 200, e00025-18. [CrossRef] [PubMed]

114. Zhang, N.; Zhang, S.; Ren, W.; Gong, X.; Long, H.; Zhang, X.; Cai, X.; Huang, A.; Xie, Z. Roles of rpoN in biofilm formation of Vibrio alginolyticus HN08155 at different cell densities. Microbiol. Res. 2021, 247, 126728. [CrossRef]

115. Han, S.; Shen, D.; Zhao, Y.; Xu, D.; Liu, J.; Chou, S.H.; Liu, F.; Qian, G. Sigma factor RpoN employs a dual transcriptional regulation for controlling twitching motility and biofilm formation in Lysobacter enzymogenes OH11. Curr. Genet. 2018, 64, 515-527. [CrossRef] [PubMed]

116. Liu, X.; Ye, Y.; Zhu, Y.; Wang, L.; Yuan, L.; Zhu, J.; Sun, A. Involvement of RpoN in regulating motility, biofilm, resistance, and spoilage potential of Pseudomonas fluorescens. Front. Microbiol. 2021, 12, 641844. [CrossRef] [PubMed]

117. Dunger, G.; Guzzo, C.R.; Andrade, M.O.; Jones, J.B.; Farah, C.S. Xanthomonas citri subsp. citri type IV Pilus is required for twitching motility, biofilm development, and adherence. Mol. Plant Microbe Interact. 2014, 27, 1132-1147.

118. Dunger, G.; Llontop, E.; Guzzo, C.R.; Farah, C.S. The Xanthomonas type IV pilus. Curr. Opin. Microbiol. 2016, 30, 88-97. [CrossRef]

119. Mohite, B.V.; Koli, S.H.; Narkhede, C.P.; Patil, S.N.; Patil, S.V. Prospective of microbial exopolysaccharide for heavy metal exclusion. Appl. Biochem. Biotechnol. 2017, 183, 582-600. [CrossRef]

120. Abdalla, A.K.; Ayyash, M.M.; Olaimat, A.N.; Osaili, T.M.; Al-Nabulsi, A.A.; Shah, N.P.; Holley, R. Exopolysaccharides as antimicrobial agents: Mechanism and spectrum of activity. Front. Microbiol. 2021, 12, 664395. [CrossRef]

121. Bhagat, N.; Raghav, M.; Dubey, S.; Bedi, N. Bacterial exopolysaccharides: Insight into their role in plant abiotic stress tolerance. J. Microbiol. Biotechol. 2021, 31, 1045-1059. [CrossRef]

122. Limoli, D.H.; Jones, C.J.; Wozniak, D.J. Bacterial extracellular polysaccharides in biofilm formation and function. Microbiol. Spectr. 2015, 3, 3. [CrossRef] [PubMed]

123. Tao, J.; He, C. Response regulator, VemR, positively regulates the virulence and adaptation of Xanthomonas campestris pv. campestris. FEMS Microbiol. Lett. 2010, 304, 20-28. [CrossRef] [PubMed]

124. Campbell, E.A.; Kamath, S.; Rajashankar, K.R.; Wu, M.Y.; Darst, S.A. Crystal structure of Aquifex aeolicus sigma(N) bound to promoter DNA and the structure of sigma(N)-holoenzyme. Proc. Natl. Acad. Sci. USA 2017, 114, E1805-E1814. [CrossRef] [PubMed]

125. Sysoeva, T.A.; Yennawar, N.; Allaire, M.; Nixon, B.T. Crystallization and preliminary X-ray analysis of the ATPase domain of the sigma(54)-dependent transcription activator NtrC1 from Aquifex aeolicus bound to the ATP analog ADP-BeFx. Acta Cryst. Sect. F Struct. Biol. Cryst. Commun. 2013, 69, 1384-1388. [CrossRef]

126. Liu, B.; Han, L.; Liu, X.; Wu, J.; Ma, Q. Computational prediction of sigma-54 promoters in bacterial genomes by integrating motif finding and machine learning strategies. IEEE/ACM Trans. Comput. Biol. Bioinform. 2019, 16, 1211-1218. [CrossRef] [PubMed]

127. Peng, Q.; Wang, G.N.; Liu, G.M.; Zhang, J.; Song, F.P. Identification of metabolism pathways directly regulated by sigma(54) factor in Bacillus thuringiensis. Front. Microbiol. 2015, 6, 407. [CrossRef] [PubMed]

128. Bono, A.C.; Hartman, C.E.; Solaimanpour, S.; Tong, H.; Porwollik, S.; McClelland, M.; Frye, J.G.; Mrazek, J.; Karls, A.C. Novel DNA binding and regulatory activities for sigma(54) (RpoN) in Salmonella enterica serovar Typhimurium 14028s. J. Bacteriol. 2017, 199, e00816-16. [CrossRef] 